\title{
PHYTOCHEMISTRY INVESTIGATION OF Casearia arborea (RICH.) URB. (SALICACEAE) AND ANTIMICROBIAL ANALYSIS OF ITS DITERPENE
}

\author{
Maria D. Leite-Ferreira ${ }^{a}$, Maria S. Rocha-Souza ${ }^{a}$, Raphael R. de A. Ramirez ${ }^{a}$, Otemberg S. Chaves ${ }^{a}$, Yanna C. F. Teles \\ Fillipe de O. Pereirac ${ }^{c}$, Raimundo Braz-Filho ${ }^{d}$, Edeltrudes de O. Lima ${ }^{a}$, Rosangela do Socorro F. R. Sarquise, Tânia Maria \\ Sarmento da Silva ${ }^{\mathrm{f}}$ and Maria de Fátima Vanderlei de Souza ${ }^{\mathrm{a}, *}$ \\ aDepartamento de Ciências Farmacêuticas, Centro de Ciências da Saúde, Universidade Federal da Paraíba, Campus I, 58051-970 \\ João Pessoa - PB, Brasil \\ bepartamento de Química e Física, Centro de Ciências Agrárias, Universidade Federal da Paraíba, Campus I, 58397-000 Areia \\ $-\mathrm{PB}$, Brasil \\ ${ }^{\mathrm{c}}$ Centro de Educação e Saúde, Universidade Federal de Campina Grande, 58175-000 Cuité - PB, Brasil \\ dDepartamento de Química, Universidade Estadual do Norte Fluminense, 28013-602 Campos dos Goytacazes - RJ, Brasil \\ eInstituto de Pesquisas Científicas e Tecnológicas do Estado do Amapá, 68901-025 Macapá - AP Brasil \\ fDepartamento de Ciências Moleculares, Universidade Federal Rural de Pernambuco, Campus Dois Irmãos, 52171-900 Recife, Brasil
}

Recebido em 13/12/2017; aceito em 08/03/2018; publicado na web em 29/03/2018

\begin{abstract}
A phytochemical investigation from aerial parts of Casearia arborea (Rich.) Urb. (Salicaceae) led to isolation and identification of: sitosterol, 4-en-stigmast-3-one, 13-hydroxy-trans-ent-cleroda-3,14-diene,3-hydroxy-2-oxo-trans-ent-cleroda-3,14-diene (kolavelone), a mixture of 13-hydroxy-trans-ent-cleroda-3,14-diene and an ester ethyl hexadecanoate, kaempferol-3-O- $\alpha$-L-arabinofuranoside and 4',5,7-trihydroxy-3',5'-dimethoxyflavone (tricin). The compounds have been described for the first time in this species. Five trihydroxy-flavone-hexoside derivatives have been identified by LC-ESI-HR-MS. The antimicrobial activity of kolavelone was evaluated against strains of Staphylococcus, Bacillus, Pseudomonas, Shigella and Candida spores, and its minimum inhibitory concentration (MIC) was determined. The results showed the antimicrobial activity of kolavelone against several bacteria and Candida tropicalis indicating its potential use as antimicrobial agent.
\end{abstract}

Keywords: Casearia arborea; Salicaceae; kolavelone; antimicrobial activity.

\section{INTRODUCTION}

Species on the family Salicaceae are known for producing a great number of bioactive substances. ${ }^{1}$ Some of its relevant compounds are lignins, terpenoids, coumarins, alkaloids, saponins and flavonoids. ${ }^{2,3}$ Anti-inflammatory and antibacterial activities are reported for Salicaceae species. ${ }^{4,5}$

The Casearia genus belongs to the family Salicaceae and the secondary metabolites of this genus include terpenoids, flavonoids, glycosides and phenylpropanoids. The literature reports the identification of 287 different types of compounds from this genus. Clerodane diterpenes seem to be the predominant group of metabolites in Casearia, many of them recently described for the first time. Isolated compounds and extracts obtained from Casearia species have shown several biological properties, including antibacterial, antiviral, cytotoxicity against tumor cells, hypoglycemic, antiophidic, antiulcerogenic and anti-inflammatory activities., ${ }^{4,6}$

Casearia arborea (Rich.) Urb. (Salicaceae) is widely used as source of wood to be used in house construction. The species occurs from Guatemala to Brazil, being popularly known as "pau de pico", "imbuí amarelo" or "canela". This paper describes the secondary metabolites obtained from the species and the evaluation of antimicrobial potential of kolavelone. A great number of studies report the antimicrobial activity of diterpenes, ${ }^{7-9}$ including clerodane type.$^{6,10}$ justifying the interest on kolavelone antimicrobial potential.

*e-mail: mfvanderlei@ltf.ufpb.br

\section{EXPERIMENTAL}

\section{Plant material}

Aerial parts of Casearia arborea (Rich.) Urb. was collected in Porto Grande - Amapá State (Brazil's North) and identified by the researcher Rosângela do Socorro F. R. Sarquis (Amapá State Institute of Technologic and Scientific Research - IEPA). A voucher specimen of plant was deposited at IEPA's Herbarium (number 2304).

\section{Extraction and isolation of compounds}

Column chromatographic (CC) has been developed using glass columns packed with silica gel 60 (Merck) 7734 (0.063-0.2 mm, 70-230 mesh) and silica gel 60 (Macherey-Nagel, particles with 0.04-0.063 mm), gel filtering chromatography (CGF) was performed using Sephadex LH-20. Thin layer chromatography (TLC) and preparative thin layer chromatography (PTLC) were carried on of silica gel PF254 plates and spots were visualized under UV light (254-366 nm) and by iodine exposure.

The plant material was dried in an oven at $40{ }^{\circ} \mathrm{C}$ for 96 hours. After milling, $1.500 \mathrm{~g}$ of stem powder and $650 \mathrm{~g}$ of leaves and flowers powder were macerated separately in ethanol $95 \%$ for 72 hours. Ethanolic extracts obtained were concentrated in a rotary evaporator, yielding $100 \mathrm{~g}$ of crude stem extract (CSE) and $80 \mathrm{~g}$ of crude leaves and flowers extracts (CLFE). Both of them were submitted to vacuum liquid chromatography (VLC) under with silica gel 60 (Merck) 7734, using as mobile phase hexane, ethyl acetate (EtOAc) and methanol $(\mathrm{MeOH})$, pure or mixtures binary. 
The hexane fraction (1.90 g) of CSE was subjected to column chromatography using silica gel eluted with hexane and EtOAc in increasing polarity mixtures, resulting 46 fractions of $50 \mathrm{~mL}$ each. The fractions were combined by TLC. Fraction $21-27(0.807 \mathrm{~g})$ were pure when analyzed in TLC, being named as compound 4 . Fraction hexaneEtOAc (9:1) (3.52 g) from the VLC was subjected to CC with silica gel using the same solvent system, obtaining 123 fractions combined by TLC analyzes. Fraction 47-50 resulted $0.101 \mathrm{~g}$ of a precipitate which was filtrated, being named as compound $\mathbf{1}$. Fraction $30(0.756 \mathrm{~g})$ was chromatographed in silica gel column using as eluents hexane and ethyl acetate in gradient mode collecting 71 fractions combined by TLC. Sub-fraction 38-58 (0.225 g) was rechromatographed in the same conditions, resulting in 31 fractions. From this procedure the combined fraction 3-10 was found to be pure compound (3) $(0.113 \mathrm{~g})$. From the same column, combined fractions 40-42 (323 g) have been chromatographed in silica gel, using hexane, dichloromethane and methanol as eluents, resulting the isolation of compound $2(0,072 \mathrm{~g})$.

The fraction hexane-EtOAc (1:1) (3.20 g) from VLC was submitted to silica gel column chromatography using hexane, ethyl acetate and methanol (gradient mode). The 186 collected fractions were analyzed and combined by TLC, purifying the compounds 5 (fractions 20-26; $0.037 \mathrm{~g}$ ) and 6 (fractions 60-94; $0.007 \mathrm{~g}$ ).

Fractions EtOAc-MeOH (9:1), EtOAc-MeOH (7:3) and EtOAc$\mathrm{MeOH}$ (1:1) from leaves and flowers have been analyzed by TLC and combined due their similarities, obtaining the combined fractions named as fraction A $(8.0 \mathrm{~g})$. The fraction A was chromatographed in a XAD-2 column using as eluents water $\mathrm{H}_{2} \mathrm{O}, \mathrm{H}_{2} \mathrm{O}: \mathrm{MeOH}(1: 1)$, $\mathrm{MeOH}$, acetone, EtOAc and hexane. The fraction $\mathrm{H}_{2} \mathrm{O}: \mathrm{MeOH}(1: 1)$, $(1.5 \mathrm{~g})$ from this procedure was chromatographed on Sephadex LH-20 using a glass column $(1,5 \mathrm{~cm}$ x $40 \mathrm{~cm})$ eluted with methanol, obtaining 101 fractions. The combined fractions 24-31 (0.200 g) was chromatographed using the same methodology, resulting in 26 fractions. The combined sub-fraction $9-22(0.048 \mathrm{~g})$ was purified by PTLC eluted with EtOAc:Hex (8:2). Each line has been separated, extracted with MeOH:EtOAc: (1:1) and filtered to obtain the compounds 7 and a flavonoid rich fraction (flavonoid fraction), lately analyzed by LC-ESI-HR-MS.

\section{Identification of isolated compounds}

The NMR spectra were obtained at: BRUKER-AC (CENAUREM/ UFC) at $500\left({ }^{1} \mathrm{H}\right)$ and $125\left({ }^{13} \mathrm{C}\right)$, VARIAN-NMR SYSTEN at $500\left({ }^{1} \mathrm{H}\right)$ and $125\left({ }^{13} \mathrm{C}\right)$ and VARIAN-MERCURY at $200\left({ }^{1} \mathrm{H}\right)$ and $50 \mathrm{MHz}$ $\left({ }^{13} \mathrm{C}\right)(\mathrm{LMCA} / \mathrm{UFPB})$. Deuterated chloroform $\left(\mathrm{CDCl}_{3}\right)$ and methanol (MeOD) were the solvents used. IR spectra were obtained through a Perkin-Elmer, FT-IR-1750 (Fourier Transform - Infra Red) and Shimadzu - IR Prestige 21 (LMCA/UFPB) device, using from 1.00 to $3.00 \mathrm{mg}$ of samples in $\mathrm{KBr}$ pellet, with frequency measured in hertz.

\section{UPLC / Xevo-G2 XS QTOF analysis of flavonoids rich fraction}

The XEVO-G2XSQTOF mass spectrometer (Waters, Manchester, UK) was connected to the ACQUITY UPLC system (Waters, Milford, MA, USA) via an electrospray ionization (ESI) interface. Chromatographic separation of flavonoids was performed on the ACQUITY UPLC with a conditioned autosampler at $4{ }^{\circ} \mathrm{C}$, using an Acquity BEH C18 column $(50 \mathrm{~mm} \times 2.1 \mathrm{~mm}$ i.d., $1.7 \mu \mathrm{m}$ particle size) (Waters, Milford, MA, USA). The column temperature was maintained at $40{ }^{\circ} \mathrm{C}$. The mobile phase consisting of $0.1 \%$ formic acid in water (solvent $\mathrm{A}$ ) and acetonitrile $0.1 \%$ formic acid (solvent B) was pumped at a flow rate of $0.4 \mathrm{~mL} \mathrm{~min}^{-1}$. The gradient elution program was $0-8 \mathrm{~min}, 10-50 \% \mathrm{~B}$; 0.8-9min, $50-95 \% \mathrm{~B}$. The injection volume was $10 \mu \mathrm{L}$.
The XEVO-G2XSQTOF mass spectrometer was used in negative ESI mode, the scan range was from 50 to $1200 \mathrm{~m} / \mathrm{z}$ for data acquisition using UPLC/MS ${ }^{\mathrm{E}}$, which allows both precursor and product ion data to be acquired in one injection. The source conditions were set as: capillary voltage, $3.0 \mathrm{kV}$; sample cone, source temperature, $100{ }^{\circ} \mathrm{C}$; desolvation temperature $250{ }^{\circ} \mathrm{C}$; cone gas flow rate $20 \mathrm{~L} \mathrm{~h}^{-1}$; desolvation gas $\left(\mathrm{N}_{2}\right)$ flow rate $600 \mathrm{~L} \mathrm{~h}^{-1}$. All analyses were performed using the lockspray, which ensured accuracy and reproducibility. Leucine-enkephalin $\left(10 \mathrm{ng} \mathrm{mL}^{-1}\right)$ was used as a standard or reference compound to calibrate mass spectrometers during analysis and introduced by a lockspray at $10 \mu \mathrm{L} \mathrm{min}{ }^{-1}$ for accurate mass acquisition. All the acquisition and analysis of data were controlled using Waters MassLynx v 4.1 software.

\section{Kolavelone (5) antimicrobial activity evaluation}

The kolavelone solution was prepared in a sterilized test tube, $900 \mu \mathrm{g}$ of kolavelone, $24 \mu \mathrm{L}$ of TWEEN 80 (emulsifying agent) and enough quantity of sterilized distilled water (for $3 \mathrm{~mL}$ ) were added. The solution was mixed for five minutes in a Vortex (FANEM/Brazil) tube stirrer, obtaining a final solution concentration of $300 \mu \mathrm{g} \mathrm{mL}^{-1}$. Serial distillations were performed using sterile liquid culture medium as diluent obtaining inferior concentrations. ${ }^{11}$

Twenty microorganism strains have been selected, divided in Gram-positive and Gram-negative bacteria and yeast-like fungi. Six of them have been obtained from the collection of Mycology Laboratory (ML), one from the Institute of Biomedical Sciences of São Paulo University (IBS-USP/SP) and 12 pattern strains from American Type Culture Collection (ATCC).

Test strains used were Staphylococcus aureus (ATCC 6538), S. aureus (ATCC 25923), S. epidermidis (ATCC 12228), Bacillus subtilis (ATCC 6633), Pseudomonas aeruginosas (ATCC 25853), P. aeruginosa (ATCC 9027), Escherichia coli (Classical C), E. coli (ATCC 18739), E. coli (ATCC 8733), Shigella flexineri (LM 412), Candida albicans (ATCC 90028), C. albicans (ATCC 76615), C. albicans (LM 142V), C. albicans (JCB 12), C. tropicalis (ATCC 13803), C. tropicalis (LM 028), C. krusei (ATCC 6258), C. krusei (LM 12), C. guilliermondii (LM 2101) and C. guilliermondii (LM 011). Stock bacteria strains were kept in Muller Hinton agar (MHA) and yeast was kept in Sabouraud dextrose agar (SDA) under refrigeration $\left(8^{\circ} \mathrm{C}\right)$.

Were used solid medium SDA and MHA, as well as Sabouraud dextrose broth (SDB) and Muller Hinton (MHB) (Difco Laboratories Ltd.) for yeast and bacteria, respectively. The preparation of medium followed manufacturer instructions. Bacteria were kept in MHA and yeast in SDA for a period of 24-48 hours at temperature of $37{ }^{\circ} \mathrm{C}$. It was prepared and standardized in sterilized physiological solution $(0.85 \%)$ containing TWEEN 80 (1\%). Each suspension had its turbidity visually compared and adjusted to those presented by barium sulfate suspension of $0,5 \mathrm{McF}$ arland scale, corresponding to

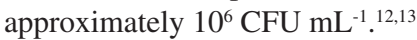

Determination of MIC was performed through the microdilution method, using 96-well microplates with "U" shaped bottom (INLAB/ Brazilian Industry). ${ }^{13,14}$ In each cavity, $100 \mu \mathrm{L}$ of double concentrated SDB or MHB were added. Then, $100 \mu \mathrm{L}$ of double concentrate kolavelone were added in the cavities of first line. By serial dilution, concentrations from $300 \mu \mathrm{g} \mathrm{mL}^{-1}$ to $9 \mu \mathrm{g} \mathrm{mL}^{-1}$ were obtained. Finally, $10 \mu \mathrm{L}$ of microbial species inoculum was added in the cavities. The following control solutions were used: TWEEN 80 (10\% in distilled water); a control with chloramphenicol (Sigma-Aldrich ${ }^{\circledR}$ ) regular antimicrobial $\left(30 \mu \mathrm{g} \mathrm{mL}^{-1}\right)$ for bacteria and ketoconazole (SigmaAldrich $\left.^{\circledR}\right)\left(50 \mu \mathrm{g} \mathrm{mL}^{-1}\right)$ for yeasts. 
The assay was performed in triplicated and incubated at $37{ }^{\circ} \mathrm{C}$ for 24 hours. After incubation time, $20 \mu \mathrm{L}$ of sodic resauzurine $\left(\right.$ Sigma-Aldrich $\left.^{\circledR}\right)$ in concentration of $0.01 \%(\mathrm{p} / \mathrm{v})$ were added as a colorimetric indicator of oxide-reduction for bacteria. For fungi, it was add $20 \mu \mathrm{L}$ of triphenyltetrazolium chloride (TTC) $1 \%$ (Sigma-Aldrich $^{\circledR}$ ), a colorimetric indicator of oxide-reduction for fungi. ${ }^{15,16}$ After incubation at $37{ }^{\circ} \mathrm{C}$, the results were obtained through visualization of color change in the cavities from blue to pink, on bacteria samples, and colorless to pink in fungal samples. This color change shows growth of microorganisms. MIC has been defined as the smallest concentration able to inhibit growing of microorganism.

\section{RESULTS AND DISCUSSION}

\section{Identification of purified compounds}

Seven compounds (Figure 1) were isolated and twelve identified from stems of $C$. arborea. Compounds $\mathbf{1}$ and $\mathbf{2}$ were isolated as a white powder precipitate soluble in chloroform. Their spectral data led to identify the compounds as sitosterol (1) and 4-en-stigmast3-one (2). ${ }^{17}$ Compound 3 was obtained as a yellow powder. The samples were analyzed by IR, NMR ${ }^{1} \mathrm{H}, \mathrm{NMR}{ }^{13} \mathrm{C}$, COSY, NOESY, HMQC and HMBC, allowing to identify them as 13-hydroxy-transent-cleroda-3,14-diene (kolavelool,3) and the compound 4 obtained as a yellow oil and identified as a mixture (43:57) because of the intensity of the signals between 13-hydroxy-trans-ent-cleroda-3,14diene (kolavelool,3) and ethyl hexadecanoate (4). ${ }^{18,19}$ Spectral data was shown at supplementary material.

Compound $\mathbf{5}$ was obtained as a green crystal. It was analyzed by IR, NMR ${ }^{1} \mathrm{H}, \mathrm{NMR}{ }^{13} \mathrm{C}$ and two-dimensional techniques, being identified as 13-hydroxy-2-oxo-trans-ent-cleroda-3,14-diene (kolavelone,5), a clerodane diterpene previously isolated in plants and sponges..$^{20,21}$ This is the first report of this substance on this family. Compound 6 was isolated as yellow powder and identified by spectral analysis as the flavone 4',5,7-trihydroxy-3',5'-dimethoxyflavone (tricin). ${ }^{22}$

The following substances have been isolated from the leaves and flowers of $C$. arborea (Figure 1). Compound 7 was isolated as a yellow powder, and after spectral analysis has been identified as kaempferol 3-O- $\alpha$-L-arabinofuranoside,${ }^{23}$ isolated for the first time on Casearia genus. ${ }^{6}$

A flavonoid rich fraction (yellow powder) was analyzed by LC-ESI-HR-MS, identifying the compounds as a mixture of five trihydroxy-flavone-hexoside derivatives (Table 1).

\section{Antimicrobial evaluation of 13-hydroxy-2-oxo-trans-ent- cleroda-3,14-diene (5)}

The antimicrobial potential of compound $\mathbf{5}$ was evaluated. Its MIC was determined through microdilution. The compound was considered active or inactive following the MIC criteria:<smiles>CC(C)[C@H](C)CC[C@H](C)[C@H]1CCC2C3CC=C4CC(O)CC[C@]4(C)C3CC[C@@]21C</smiles><smiles>CC(C)[C@H](C)/C=C/C(C)[C@H]1CCC2C3CC=C4CC(=O)CC[C@]4(C)C3CC[C@@]21C</smiles><smiles>C/C=C\C(C)(O)CCC[C@]12CCCC=C(C)[C@@]1(C)CC[C@@H]2C</smiles>

(3)<smiles>C=CC(C)(O)CC[C@]12CC(=O)C=C(C)[C@@]1(C)CC[C@@H]2C</smiles>

(5)<smiles>COc1cc(-c2cc(=O)c3c(O)cc(O)cc3o2)cc(OC)c1O</smiles>

(6)<smiles>CCCCCC(=O)OCC</smiles>

(4)

Figure 1. Isolated and identified compounds from C. arborea (Rich) Urb.

50-500 $\mu \mathrm{g} \mathrm{mL}-1=$ strong/excellent activity; $600-1500 \mu \mathrm{g} \mathrm{mL}^{-1}=$ moderate activity; over $1500 \mu \mathrm{g} \mathrm{mL}^{-1}=$ weak activity or inactive product. $^{24,25}$

Kolavelone (5) was found to be active against several bacteria strain, inhibiting bacterial growth at $300 \mu \mathrm{g} \mathrm{mL}^{-1}$ (S. aureus ATCC6538; S. aureus ATCC- 25923; S. epidermidis ATCC-12228; B. subtilis ATCC-6633; P. aeruginosa ATCC-25853; . aeruginosa ATCC-9027; E. coli (classical C); E. coli ATCC-18739; E. coli ATCC8733; S. flexneri LM-412). Staphylococcus aureus ATCC-25923 was sensible to $150 \mu \mathrm{g} \mathrm{mL}^{-1}$ of kolavelone, demonstrating its excellent antibacterial activity. Among the fungal strains, kolavelone (5) was active just against Candida tropicalis (C. tropicalis ATCC-13803; $C$. tropicalis LM-028) at a concentration of $150 \mu \mathrm{g} \mathrm{mL}$, indicating its potential use as an antimicrobial agent (Table 2).

\section{CONCLUSION}

The phytochemical investigation of Casearia arborea led to the identification of two steroids, two diterpenes, a mixture of a diterpene and a fatty acid, along with flavonoid and heteroside flavonoids, contributing to the knowledge about the secondary metabolites of the species and genus. Besides, the clerodane diterpene kolavelone presented antimicrobial activity against several bacteria and Candida tropicalis, indicating the potential of the molecule as a candidate for the development of new antimicrobial agents.

\section{SUPPLEMENTARY MATERIAL}

Supplementary information, including NMR and MS spectra (Figures 1S-74S), are available free of charge at http://quimicanova. sbq.org.br as a PDF file.

Table 1. Characterization of compounds from flavonoids fraction of C. arborea (Rich) Urb. by UPLC/QTOF-MSE

\begin{tabular}{cccccc}
\hline Compound & Retention time $(\mathrm{min})$ & $\lambda \max (\mathrm{nm})$ & {$[\mathrm{M}-\mathrm{H}]-(\mathrm{m} / \mathrm{z})$} & Calculated & Identity \\
\hline 1 & 2.84 & 264.346 & 447.0939 & 447.0933 & Trihydroxy-flavone-hexoside \\
2 & 3.01 & 264.345 & 447.0938 & 447.0933 & Trihydroxy-flavone-hexoside \\
3 & 3.08 & 264.356 & 447.0937 & 447.0933 & Trihydroxy-flavone-hexoside \\
4 & 3.18 & 264.356 & 447.0935 & 447.0933 & Trihydroxy-flavone-hexoside \\
5 & 3.43 & nd & 461.1098 & 461.1089 & Dihydroxy-methoxy-hexoside \\
\hline
\end{tabular}


Table 2. MIC values ( $\mu \mathrm{g} / \mathrm{mL}-1)$ of kolavelone $(\mathbf{5})$ on bacteria and yeasts

\begin{tabular}{|c|c|c|c|c|}
\hline \multirow{2}{*}{ Microorganisms } & \multirow{2}{*}{$\frac{\text { Compound } \mathbf{5}}{\mathrm{MIC}\left(\mu \mathrm{g} / \mathrm{mL}^{-1}\right)}$} & \multicolumn{3}{|c|}{ Controls } \\
\hline & & Tween 80 & Microorganisms & Antimicrobial \\
\hline S. aureus ATCC - 6538 & 300 & + & + & - \\
\hline S. aureus ATCC - 25923 & 150 & + & + & + \\
\hline S. epidermidis ATCC- 12228 & 300 & + & + & - \\
\hline B. subtilis ATCC - 6633 & 300 & + & + & - \\
\hline P. aeruginosa ATCC - 25853 & 300 & + & + & + \\
\hline P. aeruginosa ATCC - 9027 & 300 & + & + & + \\
\hline E. coli (clássica C) & 300 & + & + & - \\
\hline E. coli $\mathrm{ATCC}-18739$ & 300 & + & + & + \\
\hline E. coli $\mathrm{ATCC}-8733$ & 300 & + & + & + \\
\hline S. flexineri LM - 412 & 300 & + & + & - \\
\hline C. albicans ATCC - 90028 & $>300$ & + & + & - \\
\hline C. albicans ATCC -76615 & $>300$ & + & + & - \\
\hline C. albicans LM - $142 \mathrm{~V}$ & $>300$ & + & + & - \\
\hline C. albicans ICB -12 & $>300$ & + & + & - \\
\hline C. tropicalis ATCC -13803 & 150 & + & + & + \\
\hline C. tropicalis LM - 028 & 150 & + & + & - \\
\hline C. krusei ATCC -6258 & $>300$ & + & + & + \\
\hline C. krusei LM - 12 & $>300$ & + & + & - \\
\hline C. guilliermondii LM - 2101 & $>300$ & + & + & - \\
\hline C. guilliermondii LM - 011 & $>300$ & + & + & + \\
\hline
\end{tabular}

\section{ACKNOWLEDGEMENTS}

The authors thank Conselho Nacional do Desenvolvimento Científico e Tecnológico (CNPq), Coordenação de Aperfeiçoamento de Pessoal de Nível Superior (CAPES) and Fundação de Amparo a Ciência e Tecnologia de Pernambuco (FACEPE) (Grant no. PRONEM APQ-0741106/2014) for financial support.

\section{REFERENCES}

1. Mosaddik, M. A.; Banbury, L.; Forster, P.; Booth, R.; Markham, J.; Leach, D.; Waterman, P. G.; Phytomedicine 2004, 11, 461.

2. Pohjamo, S. P.; Hemming, J. E.; Willför, S. M.; Reunanen, M. H. T.; Holmbom, B. R.; Phytochemistry 2003, 2, 165.

3. Fernandes, C. C.; Cursino, L. M. C.; Novaes, J. P.; Demetrio, C. A.; Pereira-junior, O. L.; Nunez, C. V.; Quim. Nova 2009, 32, 983.

4. Philippsen, A. F.; Miguel, O. M.; Miguel, M. D.; Lima, C. P.; Kalegari, M. D. R. A.; Lordello, A. L. L.; Rev. Cubana Plant. Med. 2013, 18, 258.

5. Stanstrup, J.; Rusch, A. M.; Agnolet, S.; Rasmussen, H. B.; Molgaard, P.; Staden, J. V.; Stafford, G. I.; Staerk, D.; Biochem. Syst. Ecol. 2010, $38,346$.

6. Xia, L.; Guo, Q.; Tu, P.; Chai, X.; Phytochem. Rev. 2015, 14, 99.

7. Logoglu, E.; Arslan, S.; Öktemer, A.; Sakiyan, I.; Phytother. Res. 2006, 20, 294.

8. Tatsimo, S. J. N.; Tane, P.; Melissa, J.; Sondengam, B. L.; Okunji, C. O.; Schuster, B. M.; Iwu, M. M.; Khan, I. A.; Planta. Med. 2006, 72, 132.

9. Barni, M. V.; Carlini, M. J.; Cafferata, E. G.; Puricelli, L.; Moreno, S.; Oncol. Rep. 2012, 27, 41.

10. Maciel, M. A. M.; Dantas, T. N. C.; Câmara, J. K. P.; Pinto, A. C.; Veiga, J. R. V. F.; Kaiser, C. R.; Pereira, N. A.; Carneiro, C. M. T. S.; Vanderlinde, F. A.; Lapa, A. J.; Agner, A. R. Cóllus, I. M. S.; EchevarriaLima, J.; Grynberg, N. F.; Esteves-Souza, A.; Pissinate, K.; Echevarria, A.; Molecules 2006, 2, 22.
11. Allegrini, J.; Bouchberg, M. S.; Maillols, H.; Societ de Pharmacie de Montpellier 1973, 33, 73.

12. Cleeland, R.; Squires, E. In Antibiotics in laboratory medicine; Lorian, V., ed.; Willians \& Wikins: Baltimore, 1991, p. 739.

13. Hadacek, F.; Greger, H.; Phytochem. Anal. 2000, 11, 137.

14. Koneman, E. W.; Allen, S. D.; Dowel-Junior, V. R.; Samers, H. M.; Diagnóstico Microbiológico, Texto Atlas Ed. Méd. Panamericana, 1993, p. 452.

15. Deswal, D. P.; Chand, U.; Seed Sci. Technol. 1997, 25, 409.

16. Duarte, M. C. T.; Figueira, G. M.; Sartoratto, A.; Rehder, V. L. G.; Delarmelina, C.; J. Ethnopharmacol. 2005, 97, 305.

17. Chang, K. C.; Duh, C. Y.; Chen, I. S.; Tsai, I. L.; Planta Med. 2003, 69, 667.

18. Nagashima, F.; Suzuki. M.; Takaoka, S.; Asakawa, Y.; Nat. Prod. Res. 2001, 64, 1309 .

19. Chai, X.; Y.; Xu, Z. R.; Bai, C. C.; Zhou, F. R.; Tu, P. F.; Fitoterapia 2009, 80, 408.

20. Umeyama, A.; Shoji, N.; Teranaka, M.; Arihara, S.; Nat. Prod. Res. 1996, 59, 448.

21. Lopes, M. X.; Bomm, M. D.; Schpector, J. Z.; Phytochemistry 1999, 50, 455.

22. Jiao, J.; Zhang. Y.; Liu, C.; Liu, J.; Wu, X.; Zhang, Y.; J. Agric. Food Chem. 2007, 55, 10086.

23. Ribeiro, E. M.; Luciano, S.; Lima, L. S.; David, J. M.; Vale, A. E.; Lopes, L. M. X.; David, J. P.; Phytochem. Lett. 2013, 6, 232.

24. Sartoratto, A.; Machado, A. L. M.; Delarmelina, C.; Figueira, G. M.; Duarte, M. C. T.; Rehder, V. L. G.; Braz. J. Microbiol. 2004, 35, 275.

25. Houghton, P. J.; Howes, M. J.; Lee, C. C.; Steventon, G.; J. Etnopharmacol. 2007, 110, 391. 